\title{
Metronidazol tedavisine bağlı olarak lökopeni ve trombositopeni gelişen akut gastroenterit olgusu
}

\section{Leukopenia and thrombocytopenia due to metronidazole treatment in a case with acute gastroenteritis}

\author{
Özlem ÖZEL, Salih CESUR', Çiğdem ATAMAN HATIPOĞLU, Şerife ALTUN DEMIRCAN, Esra KAYA KILIÇ, \\ Sami KINIKLI, Ali Pekcan DEMIRÖZ
}

Ankara Eğitim ve Araştırma Hastanesi, İnfeksiyon Hastalıkları ve Klinik Mikrobiyoloji Kliniği, Ankara, TÜRKIYE

\section{öz}

Akut gastroenteritlerde tedavinin esası sıvı-elektrolit replasmanıdır. Bakteriyel veya paraziter etken düşünülen olgularda ise antibiyotik veya antiparaziter tedavi uygulanabilir. Gaitanın parazitolojik yönden incelemesi yapılmadan ampirik olarak metronidazol tedavisi başlanmamalıdır. Metronidazol antianaerobik ve antiprotozoal etkili bir ilaçtır, iyi tolere edilmesine rağmen bazı hastalarda hematolojik ve nörolojik yan etkilere neden olabilmektedir.

Bu yazıda akut gastroenterit tanısıyla metronidazol tedavisi başlanan ve metronidazole bağlı yan etki olarak lökopeni ve trombositopeni gelişen 84 yaşında bir olgu sunulmuştur. Metronidazol tedavisi sırasında veya sonrasında lökopeni, trombositopeni gibi ilaca bağlı hematolojik yan etkilerin gelişebileceği akılda tutulmalı ve yan etki gelişen hastalar yakından takip edilmelidir.

Anahtar kelimeler: Akut gastroenterit, metronidazol, yan etki, lökopeni, trombositopeni

\section{ABSTRACT}

In cases with gastroenteritis, the treatment is based on fluid and electrolyte replacement. Antibacterial or antiparasite therapy could be given in cases where bacterial or parasite microorganism is possible. However metronidazole therapy should not be initiated empirically without parasitological evaluation of the feces. Metronidazole is an antianaerobic and antiprotozoal effective drug and although it is well tolerated, it can cause hematological and neurological adverse effects in some patients. Herein, we report an 84 years old male who has given metronidazole therapy with the diagnosis of acute gastroenteritis and developed leukopenia and thrombocytopenia as side effects of the therapy. It must be kept in mind that hematologic side effects such as neutropenia and thrombocytopenia could occur during or after the metronidazole therapy and those patients should be followed closely.

Key words: Acute gastroenteritis, metronidazole, adverse effect, leukopenia, thrombocytopenia

Corresponding Authora: Dr. Salih CESUR. Ankara Eğitim ve Araştırma Hastanesi, İnfeksiyon Hastalıkları ve Klinik Mikrobiyoloji Kliniği, Ankara, TURKEY Phone:00905362592229 


\section{Giriş}

Akut gastroenteritler özellikle yaz aylarında en sık karşılaşılan infeksiyon hastalıklarının başında gelmektedir. Akut gastroenteritler inflamatuvar (invaziv) ve noninflmatuvar (noninvaziv) ishaller olarak iki gruba ayrılabilir. Akut gastroenterite neden olan başlıca etkenler bakteriler, parazitler ve virüslerdir. İnflamatuvar ishallerde dışkıda lökosit ve eritrosit saptanırken, noninflamatuvar ishallerde ise saptanmaz [1].

Entamoeba histolytica'nın neden olduğu amipli dizanteri inflamatuvar bir ishal tablosu olup tanısı dışkı mikroskopisinde direkt bakıda veya dışkının trikrom boyamasında trofozoid formların görülmesi ile konmaktadır. Amipli dizanteri tedavisinde tercih edilen antiprotozoal ilaçlar 5-nitroimidazol türevi olan metronidazol, ornidazol veya seknidazoldür. Metronidazole bağlı olarak sık bildirilen yan etkilerin başlıcaları bulantı, diyare, kuru ağız, dilde metalik tat, stomatit, periferik nöropati ve alkolle birlikte alındığında disülfiram benzeri yan etkidir [2-5] .Bu yan etkiler olguların \%2-10'unda görülür [4]. Metronidazole bağlı olarak hematolojik yan etkiler ise lökopeni, nötropeni, trombositopeni, pansitopeni ve Hemolitik Üremik Sendromu içerir [6-12]. Nadir görülen yan etkileri içerisinde ise Stevens-Johnson Sendromu, pankreatit, oftalmik toksisite ve ototoksisite yer alır [4].

Bu yazıda akut gastroenterit tanısıyla acil servise başvuran ve ampirik olarak başlanan metronidazol tedavisi sonrasında lökopeni ve trombositopeni gelişen 84 yaşında bir erkek hasta sunulmuştur.

\section{Olgu Sunumu}

Seksen dört yaşında erkek hasta ateş, karın ağrısı, ishal şikayeti ile acil servise başvurmuş ve akut gastroenterit tanısı ile metronidazol tedavisi 3x500 mg dozda başlanmıştı. Beş gün metronidazol tedavisi alan, ancak ateş, ishal yakınmaları devam eden ve oral alım bozukluğu olan hasta kliniğimize yatırıldı. Fizik muayenesinde ateşi: $36,5^{\circ} \mathrm{C}, \mathrm{TA}: 100 / 60 \mathrm{~mm} / \mathrm{Hg}$, nabız: 74/dk idi, dilde hafif kuruluk mevcuttu. Diğer sistem muayeneleri normaldi. Laboratuvar incelemesinde $\mathrm{Hb}: 11,5 \mathrm{~g} /$ dL, PLT: 65.000/ $\mu \mathrm{L}$, lökosit sayısı: 2400/ $\mu \mathrm{L}, \mathrm{C}$-reaktif protein: 2,4 $\mathrm{mg} / \mathrm{dL}$, kreatinin: 1,3 mg/dL saptandı. Gaita mikroskobisinde nadir lökosit görüldü, eritrosit ve parazit saptanmadı. Gaita kültüründe salmonella ve shigella türleri üremedi.

Hastanın metronidazol dışında aldığı başka bir ilaç tedavisi, lökopeni ve trombositopeniye neden olabilecek başka bir hastalığı ve infeksiyonu yoktu. Hastanın metronidazol tedavisi öncesindeki lökosit, trombosit değerleri normal sınırlarda iken, hemoglobin değeri düşüktü (Hb:11,8 gr/dL). Bu nedenle hastada saptanan lökopeni ve trombositopeni metronidazole bağlandı ve metronidazol tedavisi kesildi. İshal yakınması devam eden hastaya ringer laktat ile sıvı-elektrolit replasmanı yapıldı. Lökosit ve trombosit değerleri takip edildi. Yatışının üçüncü gününde PLT: 100.000/ $\mu \mathrm{L}$, lökosit sayısı: 5400/ $\mu \mathrm{L}$ 'e yükseldi, kreatin değeri ise 1,08 mg/dL'e geriledi. Hastanın yattığı sürece ateşi olmadı, ishal şikayeti ve oral alımı düzelen hasta yatışının 5. gününde taburcu edildi.

\section{Tartışma}

Metronidazol 5-imidazol türevi kemoterapötik bir ilaçtır. En sık kullanıldığı endikasyonlar; anaerobik infeksiyonlar, Entamoeba histolytica'nın neden olduğu amipli dizanteri, karaciğer amip apsesi ve diğer protozoon infeksiyonlarıdır [3,4].

Metronidazole bağlı olarak tedavi sırasında veya tedavi sonrasında çeşitli yan etkiler görülebilir. Metronidazole bağlı olarak en sık görülen yan etkiler; bulantı, diyare, kuru ağız ve dilde metalik tat gelişimidir. Alkolle birlikte alındığında disülfiram benzeri reaksiyona (yüzde kızarıklık, taşikardi, dispne) neden olur. Yüksek dozda ve uzun süre kullanımda periferik ve optik nöropatiye neden olabilir. Aseptik menenjit, ensefalopati, nöbet gelişimi, reversibl serebral sendrom diğer yan etkileridir [2-5].

Metronidazole bağlı olarak gelişen hematolojik yan etkiler nispeten nadir olup, lökopeni, trombositopeni, pansitopeni ve Hemolitik Üremik Sendromu içerir [4,6-12]. Metronidazol, normal tedavi edici dozda kullanılırken yan etkilere neden olabilir. Bu yan etkilerden nötropeninin sıklığı \%2-4 arasında değişir [8].

Metronidazolün hematolojik yan etkilerini irdeleyen pek çok yayın mevcuttur. Yirmi üç gün süreyle subakut barsak obstrüksiyonu ve amibiyazis tanılarıyla oral ve intravenöz yolla yüksek dozda metronidazol tedavisi alan 53 yaşında bir kadın hastada metronidazole bağlı olarak gelişen nötropeni bildirilmiştir. Olguda metronidazol tedavisi kesildikten sonra aşamalı olarak nötropeni düzelmiştir [8].

Martin ve ark. [9] 43 yaşında Guillain-Barré sendromu olan bir hastada aspirasyon pnömonisi nedeniyle tedaviye eklenen metronidazol tedavisi sonrasında agranülositoz geliştiğini ve metronidazol kesildikten 3 gün sonra agranülositozun düzeldiğini rapor etmişlerdir.

White ve ark. [10] sağ kolon kanseri nedeniyle hemikolektomi uygulanan 74 yaşında kadın hastaya ameliyattan 7 gün önce ve ameliyattan 10 gün sonra metronidazol tedavisi uygulandığını, ameliyattan sonraki 16. günde lökopeni geliştiğini bildirmişlerdir. Hastanın yapılan kemik iliği incelemesinde granülositopoez ve eritropoez saptandığı, hastada nötropeniye neden olabilecek metronidazol dışında bir ilaç veya viral infeksiyon olmadığı rapor edilmiştir.

McKendrick ve Geddes [11] 66 yaşında bir erkek hastada anaerobik cilt infeksiyonu tanısıyla başlanan metronidazol tedavisinden iki hafta sonra lökopeni geliştiğini bildirmişlerdir. 
Gutiérrez ve ark. [12] tedavi edici dozda intravenöz metronidazol tedavisi bir olguda ilaca bağlı olarak nötropeni bildirmişlerdir.

Sunduğumuzolgudalökopenivetrombositopeniyiaçıklayacak metronidazol dışında bir ilaç kullanımı ya da hematolojik veya infeksiyöz bir hastalık mevcut değildi. Olgumuz metronidazole bağlı olarak gelişen lökopeni ve trombositopeni olarak değerlendirildi ve izleme alındı. Metronidazol tedavisi kesildikten 3 gün sonra lökopeni ve trombositopenisi kendiliğinden düzeldi. Olgumuzda metronidazol tedavisine bağlı olarak lökopeni ile birlikte trombositopeninin görülmesi dikkat çekiciydi. Literatürde sıklıkla metronidazole bağlı olarak lökopeni veya nötropeni olguları bildirilmiştir [8,1012]. Nadiren metronidazole bağlı ilaca bağlı antikorlar aracılığı ile gelişen reversibl trombositopeni görülebilir. İlaca bağlı antikorlar aracılığı ile gelişen trombositopenide temel mekanizma çözünebilir ilaç varlığında ilaç membran proteinlerine bağlanan antikorları indükleyerek trombositopeniye neden olur. İlaca bağlı antikorlar aracılığı ile gelişen trombositopeniye enden olan başlıca antibiyotikler; beta-laktam antibiyotikler (ampisilin, amoksisislin, sefazolin, sefadroksil, sefepim, sefpodoksim, seftazidim, seftizoksim, cefazolin, cefadroxil, cefepime, cefpodoxime, ceftazidime, piperasilin-tazobaktam, lorakarbef vb.),metronidazol,siproflok sasin, nitrofurantoin, etambutoldür [13]. Sunduğumuz olguda trombositopeniye neden olabilecek başka bir ilaç kullanımı ve hastalık yoktu, bu nedenle trombositopeni de metronidazol tedavisine bağlandı. Metronidazol tedavisi kesildikten sonra hastanın trombositopenisi düzeldi.

Sonuç olarak, akut gastroenterit ile başvuran olgulara dışkıda parazitolojik inceleme yapılmadan metronidazol tedavisi başlanılmamalı, metronidazole bağlı olarak lökopeni ve trombositopeni gibi ciddi yan etkilerin görülebileceği unutulmamalıdır.

\section{Maddi Destek ve Çıkar illişkisi}

Çalışmayı maddi olarak destekleyen kişi/kuruluş yoktur ve yazarların çıkara dayalı bir ilişkisi yoktur.

\section{Kaynaklar}

1. Ulutan F. Akut ishalli hastaya yaklaşım. Willke A, Söyletir G, Doğanay M (edi), Enfeksiyöz ishaller, Enfeksiyon Hastalıkları ve Mikrobiyolojisi, 3. baskı,Nobel Tıp Kitabevleri, İstanbul, 2008; s. 1045-1078.

2. Ohniski K, Sakamoto N, Subjective adverse reaction to metronidazole in patients with amebiasis. Parasitology international 2014; 63:698-700.

3. Jenks PJ. Nitroimidazoles, In: Antibiotic and chemotherapy, Roger G. Finch,David Greenwood,Richard J, Whitley,S. Ragnar Norrby (eds). 9nd ed.Philadelphia: Saunders Company; 2010:292-300.

4. Nagel JL, Aranoff DM. Metronidazole. Mandell, Bennett, Douglas (Eds), Principles and Practice of Infectious Diseases, 8th edi, Philadelphia, Saunders Company, 2015; 353-354.

5. Vudalı E, Kınıklı S, Cesur S. Antibiyotiklerin yan etkileri. Turk J Clin Lab 2014; 5: 18-27.

6. Gilbert D, Moellering RC, Eliopoulos GM, Chambers HF, Saag MS. The Sanford Guide to Antimicrobial therapy 2012; 42nd edition, p.97-106.

7. Granowitz EV, Brown RB. Antibiotic adverse reactions and drug interactions. Crit Care Clin 2008; 24: 421-42.

8. Smith JA. Neutropenia associated with metronidazole therapy. Can Med Assoc J 1980; 123: 202

9. Martin C, Ruperti A, Saux P, Brioche MI, Gouin F. Druginduced agranulocytosis. Discussion of the responsibility of metronidazole. Ann Fr Anesth Reanim 1985; 4: 521-3.

10. White CM, Price JJ, Hunt KM. Bone marrow aplasia associated with metronidazole. Br Med J 1980; 280: 647.

11. McKendrick MW, Geddes AM. Neutropenia associated with metronidazole. Br Med J 1979; 2: 795

12. Gutiérrez García M, López Lunar E, Fernández Arenas O, Hidalgo Correas FJ, García Díaz B. Neutropenia induced by therapeutic doses of intravenous metronidazole. Farm Hosp 2009; 33: 231-3.

13. Aster RH, Curtıs BR, Mcfarland JG, Bougie DW. Drug-induced immune thrombocytopenia: pathogenesis, diagnosis, and management. J Thromb and Haemost 2009; 7: 911-8. 